The Economic Status of Asian Americans Before and After the Civil Rights Act

Harriet Orcutt Duleep

(Thomas Jefferson Program in Public Policy, College of William and Mary and IZA- Institute for the Study of Labor)

and

Seth Sanders

(Department of Economics and Sanford School of Public Policy, Duke University)

College of William and Mary

Department of Economics

Working Paper Number 135

March 2013 
WORKING PAPER \# 135

March 2013

\title{
The Economic Status of Asian Americans Before and After the Civil Rights Act
}

\begin{abstract}
In contrast to their relative standing in today's labor market, in 1960 U.S.-born men in all Asian groups earned substantially less than comparable whites. We explore explanations for the wage gap and find that all of the variables that might plausibly account for it, such as Asian/white differences in schooling, labor force participation, entrepreneurial and agricultural employment, English proficiency, enclave activity, and foreign-born parentage, have either no effect or only modest effects on the 1960 wage gap and its subsequent reduction. Our findings suggest that anti-Asian labor market discrimination was the predominate cause of the 1960 wage gap and that most of the 1960 to 1980 improvement in the relative wages of U.S.-born Asian men stemmed from a decline in anti-Asian discrimination. Although much of the policy focus of the civil rights era was directed at reducing discrimination against blacks, our findings suggest a prominent post-Civil Rights Act labor market effect for Asians. If these results hold up to further scrutiny, one interpretation is that the Civil Rights Act and accompanying activities, and/or concomitant changes in societal attitudes, benefited all minorities.
\end{abstract}

JEL Codes: J48, J71, J78, J15, J18

Keywords: anti-discrimination legislation, minority economic progress, Asian Americans, Civil Rights Act

Harriet Duleep (corresponding author)

Thomas Jefferson Program in Public Policy

College of William and Mary

Williamsburg VA 23187-8795

hduleep@wm.edu

Seth G. Sanders

Professor of Economics and Public Policy

Director, Duke Population Research Institute

Duke Sanford School of Public Policy

Box 90239, Durham NC 27708-0239

seth.sanders@duke.edu 
The Economic Status of Asian Americans before and after the Civil Rights Act

\section{Introduction}

That the average U.S.-born Asian man today earns on a par with his white statistical twin is of little surprise. In 1960, however, U.S.-born men of Japanese, Chinese, and Filipino descent earned substantially less than comparable white Americans. Twenty years later, the AsianAmerican earnings disadvantage had mostly vanished. With micro data from the 1960-1980 decennial censuses, we document this dramatic change and test various hypotheses that might explain it.

Given the surge in immigration following the 1965 Immigration and Nationality Act, the words "Asian American" and "immigrant" are often paired. Yet the Asian Americans of 1960 were not new entrants. They were generally the descendants of people who had migrated to the United States many years back. The peak of pre-1965 Chinese immigration occurred in the 1870s; the peak of Japanese immigration occurred in the first decade of the 20th century. From 1924 to 1965, antiAsian immigration legislation barred most Asians from migrating to the United States. Because of the forty-year break in Asian immigration, purely immigrant-based explanations for the large wage gap between U.S.-born whites and U.S.-born Asians in 1960 (such as the potential effect on the wages of U.S.-born Asian Americans of competing immigrants (Lalonde and Topel, 1992)) are irrelevant.

Following a large literature that examines the change in the relative earnings of AfricanAmerican men over this same time period, we ask what might explain the rapid progress in the relative earnings of Asian men between 1960 and 1980. We find that labor force selectivity and relative levels of schooling and school quality—issues central to the debate on black economic progress - are largely irrelevant to the Asian American experience. Other factors with particular 
relevance for the Asian American experience-self-employment and agricultural employment, English proficiency, enclave activity, and intergenerational assimilation — all have a very limited role in explaining the initial deficit and subsequent rise in the earnings of American-born Asians.

Beyond controls that are likely correlated with anti-Asian labor market discrimination, such as the occupations in which Asians worked, little else other than a decline in labor market discrimination can explain the stark statistics we present. Subject to further information on the within-state quality of schooling Asians and whites received, our findings suggest that anti-Asian labor market discrimination was the predominate cause of the 1960 wage gap and that improvements from 1960 to 1980 in the relative wages of American-born Asian men were almost entirely due to a decline in anti-Asian discrimination.

Throughout our analyses, the benchmark group of whites excludes persons of Hispanic ethnicity (Appendix A). For brevity's sake we will refer to non-Hispanic whites simply as whites. After describing earnings-related characteristics of U.S.-born Asian and white men in 1960 and 1980, Part II establishes a large unexplained earnings gap between U.S.-born Asians and whites in 1960 and shows that by 1980 the wage gap had narrowed appreciably. This narrowing was particularly acute for Asian men just starting careers and less prominent for Asian men midway through their careers. We further find that much of the convergence in Asian/white earnings had occurred by 1970. We then explore various hypotheses for the unexplained wage gap in 1960 and its subsequent narrowing: Part III assesses the relevance of issues that have been central to the debate on black economic progress; Part IV explores issues more narrowly relevant to Asian Americans. In Part V, we summarize our results while putting forth challenges to our discrimination-story interpretation. 


\section{The 1960 Wage Gap and Its Subsequent Narrowing}

As early as 1960 the education of U.S.-born Asians surpassed that of U.S.-born whites; only Filipino men had lower levels of schooling (Table 1). Between 1960 and 1980, the relative education of Asians versus whites hardly changed. The Asian-white ratios of average schooling years in 1960 were 1.09 for the Japanese, 1.10 for the Chinese, and .95 for the Filipinos; in 1980, the corresponding ratios were $1.08,1.18$, and .97

To assess the likely extent to which labor market discrimination may have affected the earnings of Asians in 1960, we compared the earnings of U.S.-born Asian and white men adjusting for earnings-related characteristics such as years of schooling. A finding that Asians earned substantially less than whites with similar characteristics provides potential evidence of anti-Asian discrimination.

More specifically, separate earnings regressions were estimated for each Asian group and whites,

$$
\mathrm{Y}_{\mathrm{Ai}}=\mathrm{X}^{\prime} \beta_{\mathrm{Ai}}+\varepsilon_{\mathrm{Ai}} \quad \mathrm{Y}_{\mathrm{W}}=\mathrm{X}^{\prime} \beta_{\mathrm{W}}+\varepsilon_{\mathrm{W}}
$$

where $\mathrm{Y}_{\mathrm{Ai}}$ is the natural logarithm of the earnings of Asian group $\mathrm{i}$ and $\mathrm{Y}_{\mathrm{W}}$ is the natural logarithm of the earnings of white men. Hourly earnings were computed by dividing annual earnings by annual hours-worked (Appendix A). The vector of explanatory variables, X includes years of schooling, potential work experience, marital status, region, and whether the individual resided in a metropolitan area. ${ }^{1}$ The unadjusted earnings ratios, $\mathrm{y}_{\mathrm{A}} / \mathrm{y}_{\mathrm{W}}=\exp \left(\mathrm{X}_{\mathrm{A}}{ }^{\prime} \beta_{\mathrm{A}}-\mathrm{X}_{\mathrm{W}}{ }^{\prime} \beta_{\mathrm{W}}\right)$, are shown in the

\footnotetext{
${ }^{1}$ To control for the possibility that returns to education vary with level of education, we used a two-part spline breaking at 16 years of schooling in the model specification. Sample sizes dictated a two-part rather than a three-part spline. We also estimated a two-part spline breaking at 12 years. Breaking at 16 years provides a better fit for the Asian groups. The estimated earnings regressions are available upon request.
} 
first row of Table $2 .^{2}$ Reflecting their high educational levels, the earnings of Japanese and Chinese men in 1960 exceeded white earnings. Filipino men earned substantially less. Their annual earnings, reflecting high unemployment, are particularly low relative to whites. ${ }^{3}$

The second row of Table 2 shows the adjusted earnings ratios, $\mathrm{y}_{\mathrm{A}} / \mathrm{y}_{\mathrm{W}}{ }^{*}=\exp \left(\mathrm{X}_{\mathrm{A}}{ }^{\prime} \beta_{\mathrm{A}}-\mathrm{X}_{\mathrm{A}}{ }^{\prime} \beta_{\mathrm{W}}\right)$. The predicted earnings are evaluated at Asian-specific mean levels of all explanatory variables and, hence, are geometric means for the Asian groups. Thus, the second row shows the actual mean earnings of each Asian group divided by the predicted earnings that men in that group would have earned in 1960 had they faced the white wage equation. ${ }^{4}$ In contrast to the unadjusted ratios, all adjusted earnings ratios fall substantially below parity: Japanese men in 1960 earned 23 percent less than whites with average Japanese characteristics, Chinese men earned 13 percent less than comparable whites, and Filipino men earned 39 percent less than white men with average Filipino characteristics. The hourly earnings ratios reveal similar differences. Despite small sample sizes the Asian-white earnings and wage differences are generally statistically significant. ${ }^{5}$

The lower earnings of Asians in 1960 might have occurred either because Asians were paid

\footnotetext{
${ }^{2}$ The unadjusted ratios are the ratios of Asian to white geometric means, $\mathrm{y}_{\mathrm{A}}=\exp \left(\mathrm{Y}_{\mathrm{A}}\right)$, where $\mathrm{y}_{\mathrm{A}}$ is the geometric mean of Asian earnings, and $\mathrm{y}_{\mathrm{W}}$ is similarly computed for whites. The adjusted ratios shown in Table 2 and elsewhere are computed from the anti-logs of predicted earnings based on group-specific regressions in which the dependent variable is the natural logarithm of earnings. Generally, the predicted earnings are evaluated at Asian-specific mean levels of all explanatory variables and, hence, are geometric means for the Asian groups. The analysis was also conducted using adjusted ratios of arithmetic mean earnings with no substantive difference in the results.

${ }^{3}$ U.S.-born Japanese and Chinese men were about a third as likely to be unemployed in 1960 as were white men. In contrast, the unemployment rate for Filipino men was nearly twice the rate for whites. Between 1960 and 1980, unemployment generally increased. Japanese and Chinese men retained their relative advantage, while the unemployment rate for Filipinos declined, and improved relative to whites.

${ }^{4}$ The sample sizes for the Asian groups in 1960, particularly the Filipinos, are much smaller than the available sample size for whites. Furthermore, each Asian group is geographically concentrated. By evaluating at each Asian group's means, instead of the white means, all that is required from the Asian samples is the computation of the mean and we circumvent, in this analysis, the need to use geographic coefficients estimated on very few data points for areas in which few Asians lived.

${ }^{5}$ The statistically significant results for Filipinos despite only 64 observations are due to the relatively small variance of the Filipino earnings.
} 
less than whites for doing similar work, or because Asians were disproportionately concentrated in lower paying occupations and industries given their education levels. To shed light on this issue, we evaluate white earnings at average Asian characteristics including each Asian group's distribution of occupations and industries. If Asians and whites were similarly compensated within the detailed census occupational/industrial categories included in the estimation, then adjusting for occupation and industry should eliminate the earnings gap. ${ }^{6}$ Comparing the numbers in the second and third rows of Table 2 reveals that giving whites each Asian group's occupational/industrial distribution appreciably narrows the earnings and wage gap between each Asian group and whites, especially for Chinese and Filipino men. In general, the occupational/industrial employment of Asians in 1960 appears to explain about half or more of their lower earnings relative to whites with comparable levels of education and experience. Nevertheless, the persistent earnings differences suggest that Asian men were also paid less than whites for comparable work in 1960.

Using the same explanatory variables as in the 1960 analysis, we estimated separate earnings regressions for whites and for each Asian group with 1980 census data. A comparison of the adjusted earnings ratios (Table 3) based on these regressions with the 1960 results reveals impressive gains. ${ }^{7}$ In 1960, the relative annual earnings of Asian men, $\mathrm{y}_{\mathrm{A}} / \mathrm{y}_{\mathrm{w}}{ }^{*}$, ranged from .61 for Filipino men to .87 for Chinese men; relative hourly earnings ranged from .72 for Filipinos to .85 for Chinese. In 1980, Asian relative annual earnings ranged from .94 for Filipinos to 1.06 for the Japanese and relative hourly earnings ranged from .97 for Filipino men to 1.00 for Japanese men. Thus from 1960 to 1980 there was substantial improvement in the relative earnings of all three

\footnotetext{
${ }^{6}$ The three-digit census occupational and industrial codes were used in this estimation. Since each Asian group is evaluated at its means, the actual geometric mean for each Asian group is used in the calculation of the ratios shown in Table 2.

${ }^{7}$ Note that as in the 1960 statistics, the 1980 Asian predicted earnings are simply the geometric means since we are evaluating at each Asian group's mean values of the explanatory variables.
} 
Asian groups. Improvement could have stemmed from a change in the distribution of Asian skills and characteristics. However, evaluating the 1980 Asian and white earnings regressions at the 1960 means of each Asian group (Table 3, third row) suggests that had Asian endowments of skills and characteristics remained at their 1960 levels, the change in the relative adjusted earnings of Asian men would have been even greater.

It is important to note that two aspects of our methodology work to understate both the extent of the 1960 unexplained wage gap and its subsequent improvement in the relative hourly earnings of Japanese and Chinese Americans. First, our method of computing hourly wages imparts a conservative bias to our analysis. Hours and weeks worked are continuous variables in the 1980 data; in the 1960 data, they are recorded within intervals. To make the 1960 and 1980 data comparable, we bracketed the 1980 data to match the brackets of the 1960 data and then, using the 1980 data on whites, we calculated the average weeks and hours worked within each bracket. These values were then assigned to both 1960 and 1980 brackets for all groups. ${ }^{8}$ The 1960 bracketed data indicate, however, that in 1960, Japanese and Chinese men worked more hours per annum than whites. If, as seems likely, hours and weeks worked are positively correlated with average hours worked within intervals, then our procedure of assigning Asians and whites the same hours and weeks worked within the 1960 brackets overestimates the 1960 hourly earnings of Japanese and Chinese men. This then understates the 1960 hourly wage gap of Asian men relative to white men. In 1980, U.S.-born Japanese and Chinese men worked slightly fewer annual hours than white men.

\footnotetext{
${ }^{8}$ The following were the mean values calculated from the 1980 census data used to impute values within intervals. Weeks worked: $1-13$ weeks:8.1; 14-26: 20.8; 27-39:33.1; 40-47: 42.4; 48-49: 48.3; 50-52:51.8. Hours worked per week: $1-14$ hours: $8 . .8 ; 15-29: 20.9 ; 30-34: 31.2 ; 35-39: 36.5 ; 41-48: 45.2$; 49-59: 51.9; 60+: 67.5. If actual 1980 hours and weeks were used for 1980 then the measured changes in hourly earnings from 1960 to 1980 might reflect changes from the imputed 1960 hours and weeks worked, within brackets, to the actual 1980 hours and weeks worked.
} 
Thus our imputed hours worked within intervals are higher, on average, for Japanese and Chinese men than the actual hours that they reported in 1980. Using the imputed values results in lower hourly earnings for these groups than are obtained with the more accurate 1980 data and thereby underestimates the 1960-1980 convergence in hourly earnings.

Second, our earnings analysis takes as its point of departure the basic human capital earnings function developed by Mincer (1974) in which the natural log of earnings is a function of years of experience. As is commonly done in studies comparing the earnings of various groups, our measure of the relative economic status of Asian and white men in 1960 and 1980 is their relative geometric mean earnings in those years. The geometric mean earnings for men with a particular set of earnings-related characteristics is easily calculated from the Mincer earnings function evaluated at that particular set of characteristics. Although not generally appreciated in comparative studies of earnings by race, ethnicity, nativity, and gender, this measure is sensitive to the relative earnings variances of the groups: the ratio of geometric mean earnings of two groups will equal the ratio of the arithmetic mean earnings only when the variances of the log of earnings of the two groups are equal. In our particular case, the relative earnings of each Asian group is actually lower in 1960 than is represented by the ratio of the geometric mean earnings since the variance for the earnings of white Americans in 1960 exceeds that for each group of Asian Americans in 1960.

To the extent that the Civil Rights Act and accompanying changes in the civil rights climate had an effect, we would expect there to have been an increase in the relative pay Asians received for the same work (e.g. same occupations and industries) for both men beginning their careers as well as for those within careers. However, one would expect a greater response to new job opportunities by persons beginning careers than for persons whose careers were punctuated by the Civil Rights Act: human capital investments by individuals would make mid-life occupation/industry changes 
less likely, and employers responding to the evolving civil rights climate would be more likely to change their hiring practices by hiring young workers. These considerations suggest a greater improvement in the relative earnings of cohorts beginning their careers than for cohorts whose careers were punctuated by the Civil Rights Act.

To test this hypothesis, we separately analyzed the earnings of men 25 to 44 years old and men 45 to 65 years old in 1960 and 1980 controlling for education, experience, region, and urban location. Table 4 shows the percentage effect of Asian descent on hourly earnings from regressions that pooled Asian and white observations, with whites forming the reference group. ${ }^{9}$ Comparing the coefficients in the first two columns for men 25 to 44 shows the across-cohort changes in relative Asian earnings of young men. Comparing the 1960 coefficients for men 25 to 44 years old with the 1980 coefficients for men 45 to 64 years old shows the within-cohort changes in relative Asian earnings. For all Asian groups, the improvement across the younger cohorts exceeds the with-in cohort improvement.

To investigate further the nature of change across entering cohorts versus within cohorts, we examined whether the effect of Asian descent on 1980 wages among older Asian workers is greater than among younger Asian workers largely as a result of the occupations and industries in which older Asian workers are employed. To do this we re-estimated our 1980 earnings equations controlling for the occupation and industry of each worker and then compared the effect of Asian descent of workers 25 to 44 to that of workers 45 to 64 . The third column of Table 4 presents the impact of Asian descent on wages for each age group in 1980 controlling for the workers' occupation and industry. For all three Asian groups the impact of Asian descent on wages is more

\footnotetext{
${ }^{9}$ The lack of statistical significance for most of the 1960 coefficients on Asian descent, in contrast to the analysis shown in Table 2, is due to the smaller sample sizes used here as well as evaluating the Asian effects at the pooled sample mean rather than at each Asian group's means, as was done previously.
} 
similar across age groups after controlling for the occupation and industry than before doing so (column 2).

The convergence indicates that much of the reason that older Asian workers earned less in 1980 than did their white counterparts is that older Asians were disproportionately concentrated in lower paying occupations and industries. If mid-life career changes are unlikely then this outcome might be the lingering result of past discrimination limiting the type of jobs available to Asian Americans. Further, given that controls for occupation and industry have little impact on the estimated effect of Asian descent on wages among the young, it seems that limited job opportunities affected very little the 1980 wages of new Asian job entrants. One possibility is that the Civil Rights Act (or a more tolerant environment) opened new job opportunities for Asian Americans, opportunities that were particularly important for workers entering the labor market.

Table 5 presents the occupational distribution of U.S.-born white, Japanese, Chinese, and Filipino men in 1960 and 1980 and also presents the percentage change in the fraction of men in each occupation between 1960 and 1980. U.S.-born Japanese and Chinese men in 1960 were more likely to be employed in professional and technical fields than were white men, consistent with their higher levels of education. Despite their higher levels of employment in professional and technical fields in 1960, the 1960 to 1980 growth in employment in these two high-paying occupations was at least as large for Asians as for white Americans. At the high end of the occupational distribution, Japanese and Chinese Americans increased their representation over time.

Asian Americans were also able to leave the lowest paid occupations over time at a rate that was far greater than for white American natives. For example, in 1960, Japanese and Filipino Americans were more likely to work in the lowest paid occupational category, laborer, than white Americans. As the entire economy shifted away from using common labor, all three Asian groups 
were able to reduce their employment in this low paid occupation faster than white Americans. In summary, there is some evidence that jobs in the highest paid occupations opened up for Asian Americans after 1960 and their reliance on work in the lowest paid categories decreased as well. In a pooled analysis of Asian and white observations from the 1970 census, Chiswick (1983) found the weekly earnings of U.S.-born Japanese, Chinese, and Filipino men were lower than those of whites by 4 percent, 2 percent, and 16 percent, respectively, adjusting for human capital, demographic, and geographic variables. Combining his 1970 results with our results for 1960 and 1980 suggests that much of the improvement in the relative earnings of U.S.-born Asian men occurred by 1970. To further test this supposition, we replicated our group-specific annual and hourly earnings regressions with 1970 census data. ${ }^{10}$

Using non-Hispanic whites as the comparison group, the adjusted annual earnings ratios for Japanese, Chinese, and Filipino men in 1970 are 1.00, 0.95, and 0.79 respectively; the corresponding adjusted hourly earnings ratios are $0.96,0.96$, and 0.84 . Comparing these estimates with our 1960 and 1980 ratios suggests that nearly $80 \%$ of the 20 -year earnings and wage convergence for Japanese and Chinese men was achieved by 1970 . For Filipino men at least 50\% of the 20-year earnings and hourly wage convergence was achieved by 1970 .

\section{The Relevance of Factors that Affected Black Progress}

The principle finding of this study is an impressive convergence from 1960 to 1980 in the earnings of Asians and whites with comparable characteristics. Similar studies of black men also show that following the Civil Rights Act, the earnings of black men improved substantially relative

\footnotetext{
${ }^{10}$ For this analysis we combined the two 1-percent samples from the 1970 Public Use Micro Samples (the 5\% form and the 15\% form). See Public Use Samples of Basic Records from the 1970 Census: Description and Technical Documentation, (1972) for details.
} 
to white men with comparable years of schooling and experience. Scholars have questioned, nevertheless, whether and to what extent the measured improvement stemmed from a decline in labor market discrimination as opposed to other factors, most notably an improvement in the relative quality of black education and a potentially more select black labor force as the labor force dropout rate of blacks rose over time relative to that of whites. ${ }^{11}$ These and other possible explanations for the 1960 Asian/white wage gap and its subsequent narrowing are explored below.

\section{Schooling Quality}

Much of the gain in black schooling quality resulted from the post-World War II migration of blacks from the rural South to northern cities, where expenditures on schooling were greater and where schools did not close to accommodate agricultural labor demands. In contrast, Asian Americans remained largely concentrated in the cities of just two states, California and Hawaii (Table 6). In 1960, nearly 95 percent of U.S.-born Japanese, 90 percent of U.S.-born Filipinos, and over three-quarters of U.S.-born Chinese lived in the West. Within the West, over 90 percent of Asian-Americans lived in California or Hawaii. These proportions diminished only slightly between 1960 and 1980.

To assess the direction of a possible bias in Asian-white earnings comparisons stemming from differences in schooling quality, we examined school expenditure data for the years in which the labor force participants of 1960 and 1980 were in school. Persons 25 to 65 years of age in 1960

\footnotetext{
${ }^{11}$ Relevant references include Butler and Heckman, 1977; Freeman, 1973; Heckman and Payner, 1989; O’Neill et al., 1986; Smith and Welch, 1977, 1986; and Vroman, 1974, 1990. For an analytical review, refer to Donohue and Heckman (1991). Duleep and Regets (2012) also find an abrupt unexplained improvement after 1964 in Hispanic relative earnings, in addition to blacks, using annual longitudinal Social Security earnings data matched to the CPS. In his analysis of affirmative action, Leonard (1984) found a positive effect of contractor status and compliance reviews on the employment of non-black minority males.
} 
would have received their elementary and high school education between 1900 and 1950. Members of the 1980 labor force would have been educated between 1920 and 1970. As all Asian groups are largely concentrated in California and Hawaii, the quality of education in these two states mostly determines the average quality of Asian-American education assuming that the quality of schooling Asians received in these states was similar to that received by the general population in these states. Figure 1 plots the expenditures per pupil in California and Hawaii relative to expenditures per pupil in the United States as a whole. ${ }^{12}$ As the expenditure data may reflect geographic price variations, we also examine student/teacher ratios. Figure 2 plots student/teacher ratios.

During the period in which the 1960 labor force was schooled (1900-1950), California had significantly greater resources per pupil, nearly twice as great during the early part of the 1900 s. Before 1950, Hawaii's expenditures and student/teacher ratio vacillated around the national norm. It seems likely, therefore, that the quality of schooling received by Asians in the 1960 labor force was not, on average, below the quality of schooling received by whites, subject to the major assumption that Asian and white within-state schooling experiences were similar. ${ }^{13}$

Between the years in which the 1960 and 1980 labor forces were schooled, the quality of the education received by Asians relative to whites may have decreased. Figure 1 shows that throughout the 1900s, California's expenditures per pupil fell towards the national norm. As shown in Figure 2, before 1940, California's pupil/teacher ratios were generally, with the exception of five years, below the norm; starting in 1940, they always exceeded the national norm. For Hawaii, the patterns of

\footnotetext{
${ }^{12}$ Appendix B describes how the educational expenditures series was constructed.

${ }^{13}$ Although price level data is not available by state, the Bureau of Labor Statistics does publish the CPI for major metropolitan areas. A reliable series for Los Angeles and San Francisco is available from 1914. For Hawaii, no series is available for any city until 1964. Although San Francisco and Los Angeles are currently high cost-of-living cities, this has not been true historically. For example, in 1920, the CPI for San Francisco suggests that its price level was 15\% lower than other cities in the U.S. In 1920, the price level in Los Angeles was on a par with other American cities.
} 
school expenditures in the pre-1950 and post-1950 periods are almost identical. Hawaiian pupil/teacher ratios for Hawaii vacillated around the norm before 1950 and are almost always above the norm after 1950. The declining quality of Asian American schooling, as measured by the state data, is somewhat offset by some migration of Asians from Hawaii to California. However, even if we assume that all Asians in California in 1980 were educated there, a decline in relative expenditures on Asian versus white children appears to have taken place.

As a rough estimate of how the relative schooling expenditures of the 1960 and 1980 Asian labor forces compare, Table 7 shows the average relative expenditure per student for the years in which the average 1960 and 1980 labor force members in each Asian group would have been in school. For all three Asian groups, the average relative school expenditure for the prototypical labor force member in 1960 exceeds the average relative expenditure for the prototypical 1980 labor force member. While blacks gained relative to whites in terms of schooling quality by migrating to states with higher quality educational systems, the migration to higher educational quality states that occurred for Asians appears to have been more than offset by the declining relative quality of the California primary and secondary public educational system.

In assessing the validity of our analysis it should be noted that we have assumed a positive relationship between school resources (expenditures and student/teacher ratios) and schooling quality (or at least schooling quality components relevant to earnings behavior). Yet, the relationship between school resource measures and the subsequent earnings of students is a subject of controversy. ${ }^{14}$ A cautionary note in our particular case is that despite having expenditures that

\footnotetext{
${ }^{14}$ O'Neill (1990) finds that standard measures of school resources have no effect on the wages of young men in 1987. On the other hand, for men born between 1920 and 1949, Card and Krueger (1992) find higher returns to schooling (using 1980 earnings) for individuals who were educated in states with higher than average school resources (i.e. higher teacher-pupil ratios). If there are diminishing marginal returns 
were close to the norm, the quality of public schooling in Hawaii has long been viewed as a serious problem (Fuchs, 1961). We have also assumed that average state data on expenditures and student/teacher ratios accurately portray the average within-state expenditures and student/teacher ratios of both Asians and whites. Although it is reasonable to assume that average expenditure and resource data accurately reflect the average conditions of Asian American schooling in Hawaii, where Asians have been a majority, how accurately the average state statistics reflect the historical Asian experience in California is unknown.

Subject to the validity of the schooling quality assumptions, two tentative conclusions relevant to our comparison of Asian and white earnings may be drawn. (1) To the extent that Asians earned less than whites with similar levels of education in 1960, it is unlikely that lower quality schooling was the cause. (2) To the extent that the relative earnings of Asians improved between 1960 and 1980, it is unlikely that the improvement stemmed from an improvement in the relative quality of schooling Asians received.

\section{Labor Force Participation}

The historical experience of Asians also diverges from the black experience with regard to labor force participation. Between 1960 and 1980, the labor force participation of Japanese and Chinese-American men decreased. Yet relative to whites the rates for these groups remained about the same (Table 8). The labor force participation of Filipino men actually increased in absolute as well as relative terms. The decrease in relative black labor force participation that occurred in the

to school resources, then differences in the estimated effect of school resources among studies focused on different cohorts might be due to declining geographic variation over time in school resources. It is also possible that the relationship itself between school resources and subsequent earnings has changed over time. 
1960's and 1970's has prompted concerns that the post-1964 improvement in black earnings stemmed from a relatively more select black labor force (Butler and Heckman, 1977). ${ }^{15}$ As the labor force participation of Asians relative to whites either remained constant or increased between 1960 and 1980 this issue is not relevant to the 1960 Asian-white wage gap and its subsequent elimination.

\section{Explanations Narrowly Relevant to the Asian Experience: Self-Employment and Agricultural Employment}

Certain classes of workers challenge the measurement of earnings. In particular, selfemployment and agricultural employment offer different pecuniary and non-pecuniary rewards than other types of employment. To the extent that actual compensation in these sectors is underreported, differences in the employment of Asians and whites in 1960 may have contributed to a spurious gap in compensation, and changes over time in sectoral employment may have contributed to an apparent improvement in Asian relative earnings. To control for differences in type of employment, we re-estimated our earnings regressions controlling for agricultural employment in one, and self-employment in the other.

In 1960, Japanese Americans were more than twice as likely and Filipino Americans somewhat more likely to be employed in agriculture than non-Hispanic whites: 16.2 percent of the Japanese, slightly less than one percent of the Chinese, almost 11 percent of the Filipinos, and 7.5 percent of white men were employed in agriculture in 1960. Adjusting for agricultural employment, as shown in Table 9, reduces the annual earnings gap for the Japanese and slightly

\footnotetext{
${ }^{15}$ The analysis by Vroman (1990) provides empirical evidence countering this supposition. Also refer to Brown (1984), O’Neill et al (1986, pp. 102-105), and Donohue and Heckman (1991). 
reduces it for the Filipinos, but has no effect for the Chinese. For each group, the hourly earnings gap is completely unaffected and the statistical significance of the Asian/white wage gap is increased when we control for agricultural employment.

Re-computing the Asian/white earnings ratios adjusting for self-employment slightly increases both the annual and hourly earnings ratios for the Japanese and Chinese. The reduction occurs, however, because the return to self-employment for whites in 1960 was negative. Separate estimations for Japanese and Chinese Americans in 1960 reveal that the self-employed earned more than others in the same group, holding education and experience constant, while the reverse is true of whites.

Thus, at a time when self-employment did not generally lead to higher wages, our regressions suggest that it offered Japanese and Chinese men a higher wage than their other employment options. By 1980, these large and statistically significant differences in the return to self-employment had disappeared. The fact that self-employed Japanese and Chinese Americans earned higher wages in 1960 than those in wage and salary employment indicates that selfemployment among Japanese and Chinese Americans in 1960 could not explain their lower adjusted wages relative to whites. ${ }^{16}$

\section{English Proficiency}

Although the 1960 census did not collect information on English proficiency, an analysis of 1980 census data on self-reported language proficiency reveals that even among the American born,

\footnotetext{
${ }^{16}$ Note that controlling for type of employment as we do here may underestimate discrimination since self-employment (or employment in agriculture) may be in response to discrimination. How minority responses to discrimination may affect the measurement of labor market discrimination is explored in Duleep and Zalokar (1991).
} 
English proficiency, defined as speaking only English or speaking English very well, is not universal: 99.3 percent of U.S.-born non-Hispanic white men, ages 25-64, reported speaking only English or speaking English very well compared with nearly 98 percent of U.S.-born Japanese men, 90 percent of U.S.-born Chinese men, and slightly over 93 percent of U.S.-born Filipino men. The fact that a higher proportion of U.S.-born whites report speaking only English or speaking English very well raises the possibility that poorer English proficiency among the 1960 Asian population may have contributed to their lower earnings. Our estimates of the "unexplained earnings gap" in 1960 would be exaggerated to the extent that English proficiency affected earnings and this effect was not captured by our included explanatory variables. ${ }^{17}$

Some insight into the effect on our 1960 estimates of excluding English proficiency may be gleaned by comparing the adjusted earnings ratios of Asian sub-groups who we know, from the 1980 census, have varying levels of English proficiency. If Asian/white differences in English proficiency were a major source of the 1960 unexplained earnings gap, then we would expect the unexplained gap to be greatest for the groups with the lowest English proficiency, controlling for all other explanatory variables included in our earnings estimation.

To test this hypothesis, we used the 1980 census to estimate a model in which the dependent variable is whether an individual is poorly proficient in English and the explanatory variables are those included in our wage regressions. We learn that (controlling for education, experience, and all other variables included in our earnings equation) Filipinos, the group with the largest unexplained earnings gap, are the least likely to be poorly proficient in English while the Chinese, the group with the smallest unexplained gap, are the most likely to be poorly proficient. We also know from

\footnotetext{
${ }^{17}$ In the context of a discrimination analysis, Woodbury (1991) examines the impact of English proficiency on the earnings of black, white, Asian and Hispanic immigrants.
} 
analysis of the 1980 census data that proficiency in English tends to be positively correlated with education (Table 10). Assuming that the same relationship holds in 1960, we would expect the adjusted earnings differential to be smaller for highly educated individuals than for poorly educated individuals if Asian/white differences in English proficiency were a major source of the 1960 unexplained earnings gap. ${ }^{18}$ Yet, evaluating the adjusted earnings of Asians in 1960 by education level reveals a substantial wage gap at all education levels (Table 11).

The relationships present in the 1980 census data may also be used to gauge the extent of bias caused by the omission of English proficiency in our 1960 earnings equation. Bias in the coefficients is a function of the extent to which poor English proficiency, our excluded relevant variable, is correlated with the included variables and the extent to which English proficiency affects earnings; the extent of bias for our estimated intercept is a function of the extent to which English proficiency affects earnings as well as the average level of English proficiency.

If we had information for the 1960 population on the effect of English proficiency on earnings, the correlations between English proficiency and the included variables, and the mean level of English proficiency, we could figure out the bias in our predicted earnings based on our 1960 earnings estimation. In fact, information on all these components is available for the 25-44 year old subset of the 1960 study population—the persons who are 45-64 years old in our 1980 sample. To learn how the exclusion of English proficiency affects our adjusted earnings ratios, we estimated the earnings equation for persons 45 to 65 in 1980, including and excluding English proficiency. ${ }^{19}$ As shown in Table 12, the adjusted earnings ratios based on the estimation that

\footnotetext{
${ }^{18}$ This comparison assumes that the incidence of anti-Asian discrimination is constant across education levels. This assumption is questioned and explored, using 1980 census data, in Duleep and Sanders (1992).

${ }^{19}$ In this estimation we used four English proficiency variables: "speaks only English or speaks very 
controls for English proficiency are slightly higher. However, the differences between these ratios and those based on the estimation which excludes English proficiency are minor.

An alternative approach is to estimate the extent of omitted variable bias in our 1960 earnings analysis by using the mean level of English proficiency and the correlations between English proficiency and the included variables for persons 45-84 years old in the 1980 census. By estimating an English proficiency equation on this population, we obtain relevant information for the whole 1960 population, aged 20 years. Assuming that the effect of English proficiency on earnings is the same for 1960 as it is for 1980, this information can be used to "correct" our estimated intercept and coefficients in the 1960 earnings regression. ${ }^{20}$ Evaluating the corrected white earnings regression at each Asian group's mean characteristics, including their mean levels of English proficiency, provides adjusted earnings ratios that take into account inter-group differences in English proficiency. These results are shown in Table 13. The similarity between these adjusted earnings ratios and the earnings ratios that do not use the 1980 census information to correct for

well," "speaks English well", "speaks English not well", and "speaks English not at all". Insights from this analysis are based on the assumption that the English-speaking ability of 45-64 year olds in 1980 was similar to their English-speaking ability when they were 25-44 years old.

${ }^{20}$ The correct specification is

$$
\mathrm{Y}_{\mathrm{i}}=\beta_{1}+\beta_{2} \mathrm{X}_{2}+\ldots+\beta_{\mathrm{k}-1} \mathrm{X}_{\mathrm{k}-1}+\beta_{\mathrm{k}} \mathrm{X}_{\mathrm{k}}+\varepsilon_{\mathrm{i}}
$$

where $X_{k}$ refers to English proficiency. Omitting English proficiency from the regression equation, the bias in the estimated coefficients of the included variables, $X_{i<k}$, is $E\left(\beta_{i}\right)=\beta_{i}+\beta_{k} d_{k i}$ where $d_{k i}$ is the least squares coefficient of $X_{i}$ in the equation $X_{\mathrm{ik}}=\mathrm{d}_{\mathrm{k} 1}+\mathrm{d}_{\mathrm{k} 2} \mathrm{X}_{\mathrm{i} 2}+\ldots+\mathrm{d}_{\mathrm{k}, \mathrm{k}-1} \mathrm{X}_{\mathrm{i}, \mathrm{k}-1}+\varepsilon_{\mathrm{i}}$. (Refer to Kmenta (1977, pp. 392-95). The 1980 census data on men 45-84 provided information on the mean level of English proficiency and the correlations between English proficiency and the included variables for the complete 1960 study population aged 20 years. We used the 1980 census data on men 25-64 to estimate the effect of English proficiency on earnings. In this exercise, English proficiency $\left(X_{k}\right)$ was measured as a $0-1$ variable where $X_{k}=1$ if the person reported speaking only English or speaking it very well. The estimated $X_{k}, d_{k i}$, and $\beta_{k}$ from the 1980 data were used to "correct" the estimated coefficients in the 1960 earnings equation which was then evaluated at the Asian-specific mean levels of all explanatory variables. The Asian mean levels of English proficiency were estimated from the Asian populations 45-84 years old in 1980; the mean levels of all other explanatory variables were estimated from the 1960 25-64 year old population. 
omitted variable bias provides further evidence of the stability of our results. ${ }^{21}$

Finally, it is worth considering the magnitude of the effect of English proficiency on the earnings of working-age men in 1980. To do this we added to our basic earnings model an indicator of whether each man spoke English proficiently. We defined a man as proficient in English if he reported speaking only English or reported speaking English very well. Our regression results indicate that Japanese, Chinese, and Filipino men who are English proficient earned 7.9\%, 11.5\%, and $10.4 \%$ respectively more than similar men who were not proficient in English. While these are large effects on earnings, these effects are too small to explain the enormous relative earnings increase from 1960 to 1980 of each of these groups.

For example, suppose we assume that the return to English proficiency was similar in 1960 to our measure in 1980. Then, even if all Japanese men were not English proficient in 1960 but all became proficient by 1980 , this would explain only $27 \%$ of the difference between Japanese earnings in 1960 and $1980 .^{22}$ Similar calculations for Chinese and Filipinos for both annual and hourly earnings suggests that changes in English proficiency could have explained only a small portion of the change in the relative earnings of Asians between 1960 and 1980.

\section{Foreign versus U.S.-born Parentage}

In addition to unmeasured productive characteristics, changes in other characteristics may have contributed to the decline in the unexplained earnings gap between Asians and whites. Perhaps the Asians of 1960, were they time transported to the 1980's, might face the same degree of

\footnotetext{
${ }^{21}$ The similarity in results is due to the included variables (education, age, region, and metropolitan residence) capturing much of the variation in earnings due to differences in English proficiency.

${ }^{22}$ That is of the 29 point increase in the relative earnings of Japanese men, no more than 7.9 points could be due to changes in English proficiency.
} 
discrimination as they encountered in the past. An alternative interpretation of the 1960-1980 increase in Asian relative earnings is that discrimination didn't change. Rather Asians became more like whites in terms of characteristics such as cultural interests, customs, and manner of speaking that formerly distinguished them from the white population. Such an explanation, instead of one based on diminishing discrimination, might also explain the greater relative gain across cohorts rather than within cohorts as shown in Table 4 since one might expect a steady cultural convergence across cohorts. ${ }^{23}$

To test the importance of this hypothesis, we compared Asians in 1960 who had U.S.-born parents with Asians who had foreign-born parents. Presumably, the sons of the American born would be more "culturally assimilated" than the sons of the foreign born. To the extent that the discrimination Asians faced in 1960 was a function of "cultural assimilation," we would expect the sons of the American born to out earn the sons of the foreign born, controlling for measurable skills and characteristics. Yet, group-specific earnings regressions that include whether an individual's parents were foreign or American born reveal the reverse to be true. The sons of immigrants in all Asian groups earned slightly more than the sons of U.S.-born parents, perhaps reflecting higher motivation among the former (Chiswick, 1977). ${ }^{24}$

The fact that the unexplained wage gap in 1960 was as great for the sons of Japanese, Chinese, and Filipino immigrants as for the sons of the American born in these groups suggests that

\footnotetext{
${ }^{23}$ Note, however, that there is no improvement in the 1960 adjusted earnings between persons 45 to 65 years old and the "younger generation" of persons 25 to 45 years old who presumably would have been more culturally assimilated (Table 4).

${ }^{24}$ Chiswick (1977) estimated similar results with the 1970 census. We would also expect English language proficiency to be lower among the sons of immigrants than among the sons of the native born. Thus, the fact that the sons of immigrants earn as much as the sons of the American born yields further suggestive evidence that the omission of English language proficiency in our 1960 analysis (controlling for education, age, region, and metropolitan residence) does not affect our conclusions.
} 
cultural assimilation did not underlie the 1960-1980 closing of the Asian-white wage gap. This finding does not preclude, however, the possibility that today's Asian immigrants, may face labor market discrimination, even though there is little or no unexplained wage gap in 1980 for the average U.S.-born Asian man. ${ }^{25}$ The high earnings growth of recent Asian immigrants ${ }^{26}$ suggests nevertheless that their low initial earnings are more a reflection of human capital investment than of discrimination.

\section{Regional Concentrations}

As Table 6 makes clear, Asian Americans are geographically concentrated. This raises the question of whether our analysis compares representative Asian Americans with representative white Americans.

There is no ambiguity about the representativeness of the Asian values underlying our estimated Asian/white earnings ratios: the adjusted earnings ratios for 1960 in Table 2 are the geometric mean of each Asian group divided by the predicted earnings of whites evaluated at each Asian group's mean values, including each Asian group's geographic distribution. ${ }^{27}$ Furthermore, a comparison of the coefficients on the geographic variables in group-specific wage regressions, shown in Table 14, reveals little difference for any Asian group between the wage effects of living in Hawaii versus California. Thus the Asian/white wage ratios would be little affected by

\footnotetext{
${ }^{25}$ Using 1980 census data, Duleep and Sanders (1992) find some evidence that suggests that Americanborn Asian men may face discrimination at the top.

${ }^{26}$ Evidence of high wage growth of recent immigrants is found in Duleep and Regets (1996). Duleep, Regets and Sanders (forthcoming) present a detailed analysis of the earnings growth of recent Asian immigrants including new groups such as the Vietnamese and Cambodians.

${ }^{27}$ With the small sample size of Asians in the 1960 data, it makes sense to evaluate the whites at each Asian group's characteristics rather than the reverse. In doing this, only the mean Asian earnings need to be estimated.
} 
statistically altering the residential distribution of Asians between the two states where most Asian Americans lived.

The geographic coefficients from the white wage regression (Table 14) reveal that the coefficient on California is similar to the coefficients for North Central and West; altering the geographic distribution of whites across these areas would have little effect on the Asian/white wage ratios. In contrast, the coefficient on Hawaii greatly exceeds the other geographic coefficients in the white wage regression. This raises the possibility that our estimated 1960 Asian/white wage gap is the product of the over-representation in our analysis of atypical whites who lived in Hawaii and earned exceptionally high wages. Given the potential sensitivity of our estimated wage ratios to differences in the residential patterns of Asians and whites, we re-estimated the predicted wages that underlie these ratios and imposed the white geographic distribution on each Asian group.

Estimating white wages at the white geographic distribution decreases the white predicted wages: the predicted white wage decreases from $\$ 3.05$ to $\$ 2.81$ when evaluated at the white instead of the Japanese geographic distribution; from $\$ 2.95$ to $\$ 2.83$ when evaluated at the white instead of the Chinese distribution; and from $\$ 2.67$ to $\$ 2.43$ when evaluated at the white instead of the Chinese distribution. Estimating each Asian group's earnings at the white geographic distribution also decreases the Asian predicted earnings since Asians living in California and Hawaii earned more than comparable Asians living elsewhere. Because of the parallel effects for Asians and whites of imposing the white geography, the resulting Asian/white wage ratios, other than the Chinese/white wage ratio, are little changed from those presented in Table 2. The new Asian/white wage ratios are .77 for the Japanese, .74 for the Chinese, and .75 for the Filipinos. 


\section{Enclaves}

Beyond being geographically concentrated at a state level, the existence of Asian ethnic enclaves may have affected the 1960 wages of Asian Americans; a subsequent dissolution of enclaves could then explain the growth in Asian relative wages.

There are a variety of possible reasons for the development of enclaves. Enclave economies could arise in response to labor market discrimination. We would then expect that the wages of Asians who had access to enclave employment would be higher than those without the enclave employment option.

Several nondiscrimination models for enclave employment are also possible. Asians might have preferred to work in enclave economies because they offered non-pecuniary benefits unavailable in the non-enclave economy. The wages of whites would then equal the wages of Asians plus the value of the nonpecuniary benefit to Asians of working in an enclave. Over time, the value of this nonpecuniary benefit for Asians may have declined, and the wages of Asians and whites would have converged.

Lang (1986) argued that it is expensive for persons who speak a different "language" to work together. Language in this model need not entail a different spoken language, but may include different styles of communication, such as differences in how women and men, or blacks and whites, communicate. The market will try to minimize these costs and "same language" enclaves may develop (Lang, 1986). The resulting employment segregation could be accompanied by differences in the nominal wage and price structures of the enclaves and non-enclave economies. (Such differences would not be captured by the regional and urban controls in our earnings estimations.) Over time, as modes of communication converged, the enclaves would dissipate and Asian and white wages would converge. 
Regardless of the reason for the existence of enclaves, in order for enclaves to "explain" the Asian-white wage gap in 1960, the adjusted wages of Asians in enclaves would have to be lower than the adjusted wages of Asians outside of enclaves. Although we cannot directly measure the wages of Asians in enclaves versus those not in enclaves, we can produce indirect evidence of the enclave effect by examining the wages of those most likely to be in enclaves versus those least likely to be in enclaves.

A key feature of ethnic enclaves is the employment of persons by members of the same ethnic group. Hence, ethnic enclaves are associated with higher than usual self-employment rates. Keeping in mind that all of the individuals in the groups are U.S. born, we find that in 1960 only Japanese Americans were more likely to be self-employed than whites: $22.5 \%$ of the Japanese Americans, $15.8 \%$ of the Chinese Americans, and 3.1\% of the Filipino Americans were selfemployed compared with $16.9 \%$ of the whites.

Disaggregating by birth cohort reveals an over time transition. ${ }^{28}$ For cohorts born before 1931, both Japanese and Chinese Americans tended to be more likely to be self-employed than whites of the same birth cohort. For instance, for the cohort born in 1916-20, 28\% of the Japanese and $24 \%$ of the Chinese were self-employed, compared with $20 \%$ of the whites; for the $1921-25$ birth cohort, $26 \%$ of the Japanese and $24 \%$ of the Chinese, compared with $16 \%$ of the whites were self-employed. Starting with the cohort born in 1931-35, the Japanese and Chinese self-employment rates were generally similar or below those of whites. Filipino rates are uniformly low across all birth cohorts.

If ethnic enclaves were an important cause of the lower wages of Asian Americans in 1960,

\footnotetext{
${ }^{28}$ The overall averages presented are based on the 1960 census. Due to the small sample sizes in the 1960 census, the self-employment rates by cohort are based on 1980 census data.
} 
we would expect that Filipino Americans would have higher adjusted wages than the other Asian groups, and that Japanese and Chinese Americans born in earlier cohorts would have lower wages in 1960, relative to whites of comparable age and education, than Japanese and Chinese Americans in more recent cohorts. And yet we find the reverse to be true.

The indirect evidence presented above suggests that enclaves improved the earnings of U.S.-born Asians in 1960 from what they otherwise would have been. ${ }^{29}$ As such, the existence of enclaves in 1960 cannot explain the 1960 Asian/white wage gap, and by inference, any over-time decrease in enclave activity cannot explain the 1960-1980 convergence in the adjusted wages of Asian and white Americans.

V. Conclusions and Further Comparisons with the African-American Experience Using 1960 census data, we find a large unexplained wage gap between Asians and whites for U.S.-born men of Japanese, Chinese, and Filipino descent. By 1980, this gap had almost disappeared for men 25-44 years old and was reduced by half for men 45-64 years old.

With respect to a decline in the black/white wage gap over the same period, questions have arisen concerning to what extent reduced labor market discrimination was a contributing factor. Other potentially relevant factors, which are difficult to explicitly take into account, include a relative improvement in the quality of schooling blacks received and perhaps a more select labor force. On the basis of residential location, schooling expenditures, and student/teacher ratios, unmeasured differences in school quality provide an unlikely explanation for the changing earnings

\footnotetext{
${ }^{29}$ This conclusion is also based on ongoing work in which we create a proxy for the likelihood of a person being in an enclave, using an Asian concentration measure. Our additional analysis supports the conclusion that in 1960 Asian Americans with greater access to enclave employment had higher wages than otherwise similar Asian Americans with less access to enclave employment.
} 
patterns of Asian Americans. Historical research is needed, however, on the extent of within-state differences in the schooling received by Asians and whites.

Since the relative labor force participation of Asians either remained constant or increased between 1960 and 1980, the rise in Asian relative earnings cannot be attributed to declining Asian labor force participation relative to whites. Asian/white differences in entrepreneurial and agricultural employment, English proficiency, foreign versus U.S.-born parentage, geographic concentration and enclave activity also fail to explain the 1960 wage gap and its subsequent narrowing. Subject to further work on Asian/white schooling quality, our findings suggest that antiAsian labor market discrimination was the predominate cause of the 1960 adjusted wage gap and that much of the subsequent rise in the relative earnings of U.S.-born Asian men was likely the result of a decline in anti-Asian labor market discrimination.

If these results hold up with further analysis, one interpretation is that the Civil Rights Act and accompanying activities generally benefited all minorities. Viewed in this broader perspective, several questions arise that challenge our interpretation and may inspire further research.

For instance, if the Civil Rights Act and accompanying activities were responsible for the convergence in the adjusted wages of Asian and white Americans, why did the path to Asian-white wage convergence differ so much from the path to black-white convergence? Asians in 1960 had higher average years of schooling and, during the period considered, do not seem to have gained in educational achievement against whites. In contrast, black men were far less educated on average than whites in 1960 and the narrowing education gap has been an important part of the black-white income convergence (e.g. O’Neill et al, 1986; Smith and Welch, 1986; Juhn, Murphy, and Pierce, 1991).

The difference in educational attainment between Asians and blacks may be explained by 
differences in their respective returns to education. Studies focused on black-white differences have found that the historical return to black education was lower than the return faced by whites (e.g. O’Neill et al. 1986.). In contrast, our estimated wage regressions show very little difference in the return to schooling between Asians and whites. Evaluated at 20 years of work experience, the coefficients from the 1960 group-specific regressions on the natural log of hourly earnings are .064 for non-Hispanic whites, .074 for Japanese Americans, .078 for the Chinese Americans, and .067 for Filipino Americans. ${ }^{30}$ Rather than being caused by a lower return to education and experience, the lower adjusted wages in 1960 of Asians relative to whites is due to the much lower intercept of each Asian wage equation relative to the white equation. That is, Asians earned roughly a constant percentage less than whites at all levels of schooling, ${ }^{31}$ whereas the black deficit in 1960 tended to be higher at higher levels of schooling than at lower levels (e.g. O’Neill et al, 1986).

A returns-to-schooling explanation for the differential educational histories of blacks and Asians begets another question: why was there a fairly uniform wage gap across education levels for Asians but not for blacks? One possible route for exploring such inter- and intra-group variations in adjusted minority-white wage gaps is to examine the supply responses of minorities to discrimination (Duleep and Zalokar, 1991).

There is also a contrast between blacks and Asians in the timing and magnitude of wage convergence. Black-white income convergence continued until the late 1970s (Juhn, Murphy, and Pierce, 1991). Yet, we find that much of the Asian-white convergence occurred by 1970 . Between

\footnotetext{
${ }^{30}$ These estimates are based on a specification in which education was entered linearly and interacted with experience. Estimates shown in the tables were based on a specification that included two education splines, and an interactive term with experience. Full earnings regression results using both specifications are available from the authors.

${ }^{31}$ This is apparent in Table 11 where we evaluate the Asian-white hourly wage ratios at different levels of schooling.
} 
1963 and 1979, weekly wages for black men increased .6 percent faster per annum than wages for whites (Juhn, Murphy, and Pierce, 1991). The corresponding Asian statistics for adjusted hourly wages between 1960 and 1980 is 1.1 for Japanese Americans, .7 for Chinese Americans and 1.25 for Filipino Americans; between 1960 and 1970, Japanese, Chinese and Filipino wages grew 2.3, 1.3, and 1.6 percent faster per year than the wages for whites. To the extent that the Civil Rights Act and accompanying activities were responsible for the growth in Asian and black relative wages, what explains the faster growth in Asian as opposed to black relative wages?

In a study that uses annual longitudinal Social Security earnings data matched to the Current Population Survey, Duleep and Regets (2012) also find an abrupt, large unexplained improvement after 1964 in Hispanic earnings, relative to non-Hispanic white earnings, that exceeds the concomitant change for African Americans. One possible explanation for further inquiry is that employers may have responded more readily to the Civil Rights Act for non-black minorities than they did for blacks because of lower levels of employer and employee prejudice against Asians and Hispanics. Alternatively, our finding of an unexplained convergence on white earnings by nonblack minorities may suggest that there was some economy-wide factor that we are falsely attributing to the Civil Rights Legislation. ${ }^{32}$

Our analytical approach has been to eliminate explanations other than discrimination for the 1960 Asian/white wage gap and then infer that the closing of the Asian/white adjusted wage gap was due to a decline in discrimination plausibly induced by the Civil Rights Act and accompanying activities. This process-of-elimination approach would be usefully supplemented by more direct

\footnotetext{
${ }^{32}$ In an analysis that makes no functional form assumption concerning the time trend, Duleep and Regets (2012) find consistent improvement for Mexican-Americans immediately following the 1964 Civil Rights Act. It is difficult to reconcile this abrupt and very large change with a coincident change in the economy.
} 
evidence on how the Civil Rights Act and accompanying activities affected Asian Americans. In his analysis of affirmative action, Leonard (1984) found a positive effect of contractor status and compliance reviews on the employment of non-black minority males. To the extent that this paper provides evidence of a legislatively induced decline in discrimination, what were the respective roles of the Civil Rights Act itself and accompanying activities such as the EEOC?

At a minimum, our analysis suggests that a broader focus on all of the groups who were covered by the Civil Rights Act may further illuminate the nexus among Civil Rights legislation, societal attitudes, and minority economic status. 


\section{Appendix A: Sample Selection and Other Methodological Issues}

To establish a statistical basis for examining the issue of discrimination, census data were used to compare the labor market performance of U.S.-born Asian and white men in 1960 and in 1980 adjusting for characteristics that affect earnings but are not themselves believed to be directly affected by labor market discrimination

The earnings estimations were done using the 5 percent "A" Public Use Sample of the 1980 Census of Population and the 1 percent Public Use Sample of the 1960 Census of Population (Bureau of the Census,1983; Bureau of the Census, 1975). The 1960 census data are considerably more limited than the 1980 census data with respect to earnings-related characteristics. Fewer earnings-related variables are available and the variables that are available often convey less information than analogous 1980 census variables. For instance, the information concerning where individuals live is less precise, and the 1980 census reports the hours and weeks worked by individuals whereas such information is available only within brackets in the 1960 census. As such, careful attention was paid to making the earnings analyses comparable across census years.

Otherwise, changes in the relative earnings of Asian men might reflect differences in how groups were defined, how earnings-related variables were controlled, or how hourly earnings were computed. Only variables available in both censuses were used in the inter-temporal analysis; for the subset of variables common to both censuses, the 1980 data were recoded to reflect the more limited 1960 information.

All analyses, except for the computation of labor force participation rates, exclude students and the military and include only persons who worked at least one week and had non-zero earnings in 1979. Sample size information is provided in Table A-1.

Differences between the 1960 and 1980 census data required limiting the groups that were 
studied. Although a 5 percent Public Use Sample of the 1980 census is available, only a 1 percent sample of the 1960 census is available for detailed analysis; the small size of the 1960 sample makes the study of U.S.-born Koreans, Asian Indians, and Vietnamese impractical. Furthermore, only second-generation individuals in these groups can be identified in the 1960 census.

Consequently, the 1960-1980 comparison is limited to U.S.-born Japanese, Chinese, and Filipinos, who were identified as separate races in both the 1960 and 1980 data.

From the benchmark group of whites, we excluded Hispanics, a group potentially affected by labor market discrimination. Although the 1980 data facilitate a careful delineation of this group that excludes Hispanics, the 1960 data are more limited. Hispanics can be identified in the 1960 data according to whether parents were born in a Hispanic country. However, parental origin is not available in the 1980 data. Language spoken at home could also have identified Hispanics; however, this question was not asked of the American born in 1960. Hispanics can be identified with the 1960 data by whether an individual reported a Spanish surname (available only if the person resided in one of five Southwestern states) and whether the person was of Puerto Rican stock. Spanish surname and Puerto Rican origin are similarly defined in the 1980 census. To ensure that the benchmark groups were comparable in the 1960 and 1980 data analyses, U.S.-born non-Hispanic whites were defined in both years as U.S.-born whites who do not have a Spanish surname (given that they reside in one of five Southwestern states) and who are not of Puerto Rican origin.

The 1980 census provides much more detailed information about the location of households within a metropolitan area than the 1960 census. In 1960, a distinction can be made only between households inside and outside an SMSA. To ensure comparability between the 1960 and 1980 data, individuals are coded as non-metropolitan in the 1980 data if they reside outside an SMSA. Similarly, individuals are coded as nonmetropolitan in the 1960 data if they reside outside an 
SMSA, or if the metropolitan status of a household is not identified but the household is found in a rural area, or if the metropolitan status of a household is not identified but the individual works outside an SMSA.

In addition to the differential treatment of hours and weeks worked in the 1960 and 1980 censuses, discussed in the text, hours worked in the 1960 census data refer to the hours worked in the census survey week; the 1980 census data refer to usual hours worked per week in 1979.

For individuals with earnings above the reporting limit $\$ \$ 75,000$ in 1980 and $\$ 25,000$ in 1960) earnings were imputed using the Pareto method (refer to Bureau of the Census, 1983, page 164). Earnings include self-employment income. 
Table A-1: Samples Sizes for American-Born Men in the Labor Force, Ages 25-64

$$
\begin{aligned}
& \text { Japanese Chinese Filipino Non-Hispanic } \\
& \text { white }
\end{aligned}
$$

1960 sample

size

764

209

64

29,513

1980 sample

size

5,976

1,972

1,246

48,037

$\overline{1960}$ Census of Population 1 percent Public Use Sample and 1980 Census of Population 5 percent "A" Public Use Sample

Notes: A random sample of 1-in-1000 was used for non-Hispanic whites given the large number in this group. The labor force, as defined here, excludes students and the military and consists of persons who worked at least one week and had non-zero earnings in 1959 (for the 1960 sample) or in 1979 (for the 1980 sample). 
Appendix B

Calculating State Educational Expenditures per Student and Student-Teacher Ratios

The data to compute our time series on state educational expenditures per student and students per teacher comes from the annual Statistical Abstract of the United States for the years 1900 to 1971. The Statistical Abstract reports per pupil expenditures by state. However, the calculation of this figure varies over time: before 1930, the Statistical Abstract reports educational expenditures per capita population ages 5 to 17; between 1930 and 1942, it reports expenditures per enrolled student; and after 1942, it reports expenditures per student adjusted by the average daily attendance in each state. Apparent changes in expenditures per student might occur as the manner of calculating the series changed. In particular, if California and Hawaii had above average daily attendance, then an apparent drop in expenditures per student relative to the U.S. average would occur in those states beginning in 1942. Hawaii did, in fact, have above average daily attendance for most years after 1942. One cannot determine what was the average daily attendance in California relative to the rest of the U.S., for most years after 1942, since California excludes "Excused Absences" from their calculation of average daily attendance while no other state has this practice; the bias in using the series reported in the Statistical Abstract is not, in this case, apparent.

We constructed a series of state educational expenditures per pupil which is consistent over time. Since information on average daily attendance is not available before 1942, we constructed our series as simply the ratio of total current educational expenditure in any year divided by the students enrolled in that year. Information to construct such a series is available, usually biannually, since 1900. Current expenditures exclude expenditures on summer school and adult education as well as expenditures on capital outlays and interest payments. While we recognize that capital outlays are a substitute for current expenditures, it is not clear how to price the 
current value per year of these outlays.

The number of teachers employed in primary and secondary education in each state has been reported since 1900. As an alternative measure of the average quality of education in a state we use the ratio of students per teacher. This is computed directly from the total student enrollment and the total number of teachers employed in each state as reported in the Statistical Abstract. 


\section{References}

Becker, Gary S., The Economics of Discrimination, Second Edition, Chicago: The University of Chicago Press, 1971.

Brown, Charles, "Black-White Earnings Ratios Since the Civil Rights Act of 1964: The Importance of Labor Market Dropouts," Quarterly Journal of Economics, May 1984, 99, 31-44.

Butler, Richard and Heckman, James J., "The Government's Impact on the Labor Market Status of Black Americans: A Critical Review," in Equal Rights and Industrial Relations, ed. Leonard J. Hausman, et al., Madison, Wisconsin: Industrial Relations Research Association, 1977, 235-81.

Card, David and Alan Krueger, "Does School Quality Matter? Returns to Education and the Characteristics of Public Schools in the United States," Journal of Political Economy, 1992.

Chiswick, Barry R., "An Analysis of the Earnings and Employment of Asian-American Men", Journal of Labor Economics, April 1983, 197-214.

—, "The Economic Progress of Immigrants: Some Apparently Universal Patterns," in William Fellner, editor, Contemporary Economic Problems 1979, Washington, D.C.: American Enterprise Institute, 1979.

-, "Sons of Immigrants: Are They at an Earnings Disadvantage?,"American Economic Review, February 1977, 376-380.

Duleep, Harriet Orcutt and Mark C. Regets, "The Civil Rights Act and the Earnings of Lower Income Hispanic Men in the 1960's," IZA Discussion Paper, 2012.

—, "Measuring Immigrant Wage Growth Using Matched CPS Files," Demography, May 1997, vol. 34 , no. 2, pp. 239-249.

Duleep, Harriet Orcutt, Mark C. Regets, and Seth Sanders, Skills, Investment, and Family Ties: A Study of Asian Immigrants, forthcoming.

Duleep, Harriet Orcutt and Seth Sanders, "An Exploratory Analysis of Discrimination at the Top: American-Born Asian and White Men," Industrial Relations, Fall 1992.

Duleep, Harriet Orcutt and Nadja Zalokar, "The Measurement of Labor Market Discrimination When Minorities Respond to Discrimination," in Richard R. Cornwall and Phanindra V. Wunnava, eds., New Approaches to Economic and Social Analyses of Discrimination, NY: Praeger Press, 1991.

Donohue, John J. and Heckman, James, "Continuous Versus Episodic Change: The Impact of Civil Rights Policy on the Economic Status of Blacks," Journal of Economic Literature, vol. 29, no. 4, December 1991, pp. 1603-1643.

Freeman, Richard B., "Changes in the Labor Market for Black Americans," Brookings Papers on Economic Activity, 1: Spring 1973, 67-120.

Fuchs, Lawrence, Hawaii Pono: A Social History, 1961

Heckman, James J., “Accounting for the Economic Progress of Black Americans,” in eds. Richard R. Cornwall and Phanindra V. Wunnava, New Approaches to Economic and Social Analyses of Discrimination, New York: Praeger, 1991.

—, and Payner, Brook S., "Determining the Impact of Federal Antidiscrimination Policy on the Economic Status of Blacks: A Study of South Carolina," The American Economic Review, March 1989, 79, 138-177.

Lang, Kevin., “A Language Theory of Discrimination,” Quarterly Journal of Economics, 1986, 
363-382.

Leonard, Jonathan S., "The Impact of Affirmative Action on Employment," Journal of Labor Economics, 1984, vol. 2, no. 4, pp. 439-462.

Mincer, Jacob, Schooling, Experience, and Earnings, New York: Columbia University Press and NBER.

O'Neill, June, "The Role of Human Capital in Earnings Differences Between Black and White Men," Journal of Economic Perspectives, vol. 4, Fall 1990, pp. 25-45.

- , and Cunningham, James, Sider, Hal, and Sparks, Andrew, The Economic Progress of Black Men, U.S. Commission on Civil Rights, Washington, D.C.: Government Printing Office, 1986.

Smith, James and Welch, Finis, "Black-White Male Wage Ratios: 1960-1970", The American Economic Review, 1977, 67, 323-38.

-, Closing the Gap: Forty Years of Economic Progress for Blacks, Santa Monica, Calif.: Rand, 1986.

U.S. Bureau of the Census, Census of Population and Housing, 1980: Public Use Microdata Samples, Technical Documentation, Washington, D.C.: Bureau of the Census, 1983.

—, Public Use Samples of Basic Records from the 1970 Census: Description and Technical Documentation, Washington, D.C.: Bureau of the Census, 1972, reprinted 1977.

—, A Public Use Sample of Basic Records from the 1960 Census, Description and Technical Documentation Washington, D.C.: Bureau of the Census, 1975.

-, Statistical Abstract, Washington, D. C.: Bureau of the Census, annual reports for 1901-1971.

U.S. Commission on Civil Rights, The Economic Status of Americans of Asian Descent, Washington, DC: Government Printing Office, 1988.

Vroman, Wayne, "Changes in Black Worker's Relative Earnings: Evidence for the 1960's," in G. Von Furstenberg, ed., Patterns of Racial Discrimination, Vol. II, Lexington, Mass.: D.C.Heath 1974.

—, "Black Men's Relative Earnings: Are the Gains Illusory?," Industrial and Labor Relations Review, October 1990, pp. 83-98.

Woodbury, Stephen A., "Earnings of Black Immigrants: Implications for Racial Discrimination," in eds. Richard R. Cornwall and Phanindra V. Wunnava, New Approaches to Economic and Social Analyses of Discrimination, New York: Praeger, 1991. 
Table 1: Years of Schooling Completed for American-born Men 25-64 Years Old, 1960

$$
\begin{gathered}
\text { Average Years of } \\
\text { Schooling Completed }
\end{gathered}
$$

Japanese

Chinese

Filipino

White
11.71

11.90

10.23

10.72
Percent

College Graduate

15.1

27.3

6.3

11.7 
Table 2: Asian/White Ratios of Unadjusted Earnings and Adjusted Earnings Evaluated at Asian-Specific Values of Skills and Characteristics, American-Born Men, Ages 25-64, 1960

$$
\text { (t-statistics in parentheses) }
$$

$$
\text { Japanese Chinese Filipino }
$$

Annual Earnings

unadjusted

adjusted

controlling for occupation and industry

Percent of gap explained adjusting for occupation and industry

Hourly Earnings

unadjusted

adjusted

controlling for occupation and industry

Percent of gap explained adjusting for occupation and industry

$\begin{array}{ccc}1.08 & 1.12 & 0.73 \\ 0.77^{* *} & 0.87 & 0.61^{* *} \\ (-2.18) & (-1.45) & (-3.05)\end{array}$

0.88

0.90

0.72

$47 \%$

$75 \%$

$62 \%$

1.01

1.07

0.83

$0.78^{* *}$

$0.85^{*}$

$0.72^{* *}$

$(-2.22)$

$(-1.80)$

$(-2.11)$

0.92

0.91

0.83

$31 \%$

$50 \%$

$53 \%$

"Difference in predicted log earnings is statistically significant at .05 level. * Difference in predicted log earnings is statistically significant at .10 level.

Notes: The unadjusted ratios are the ratios of Asian to white geometric means. The adjusted ratios shown here and elsewhere are computed from the anti-logs of predicted earnings based on group-specific regressions in which the dependent variable is the natural logarithm of earnings. Generally, the predicted earnings are evaluated at Asian-specific mean levels of all explanatory variables and, hence, are geometric means for the Asian groups..T-statistics for the difference in predicted log earnings are shown in parentheses. 
Table 3: Asian/White Ratios of Unadjusted Earnings and Adjusted Earnings Evaluated at Asian-Specific Values of Skills and Characteristics, American-Born Men, Ages $25-64,1980$

$$
\text { (t-statistics in parentheses) }
$$

Annual Earnings

$$
\text { Japanese Chinese Filipino }
$$

$\begin{array}{lccc}\text { unadjusted } & 1.14 & 1.10 & 0.88 \\ \text { adjusted } & 1.06^{*} & 0.98 & 0.94^{*} \\ & (1.93) & (-0.86) & (-1.76) \\ \text { evaluated at } 1960 & 1.11^{* *} & 1.02 & 0.98 \\ \text { Asian means } & (3.12) & (0.53) & (-0.40)\end{array}$

Hourly Earnings

unadjusted

1.12

1.13

0.94

adjusted

1.00

0.99

0.97

$(0.07)$

$(-0.45)$

$(-1.06)$

evaluated at 1960

1.04

0.98

1.01

Asian means

(1.39)

$(-0.71)$

(0.26)

\footnotetext{
** Difference in predicted log earnings is statistically significant at .05 level.

Difference in predicted log earnings is statistically significant at .10 level.

Notes: The unadjusted ratios are the ratios of Asian to white geometric means. The adjusted ratios shown here are computed from the anti-logs of predicted earnings evaluated at 1980 and 1960 Asian-specific mean levels of all explanatory variables. T-statistics for the difference in predicted log earnings are shown in parentheses.
} 
Table 4: Percentage Effect of Asian Descent on Hourly Earnings, Controlling for Education, Experience, Region, and Urban Location of American-Born Men by Age Category in 1960 and 1980

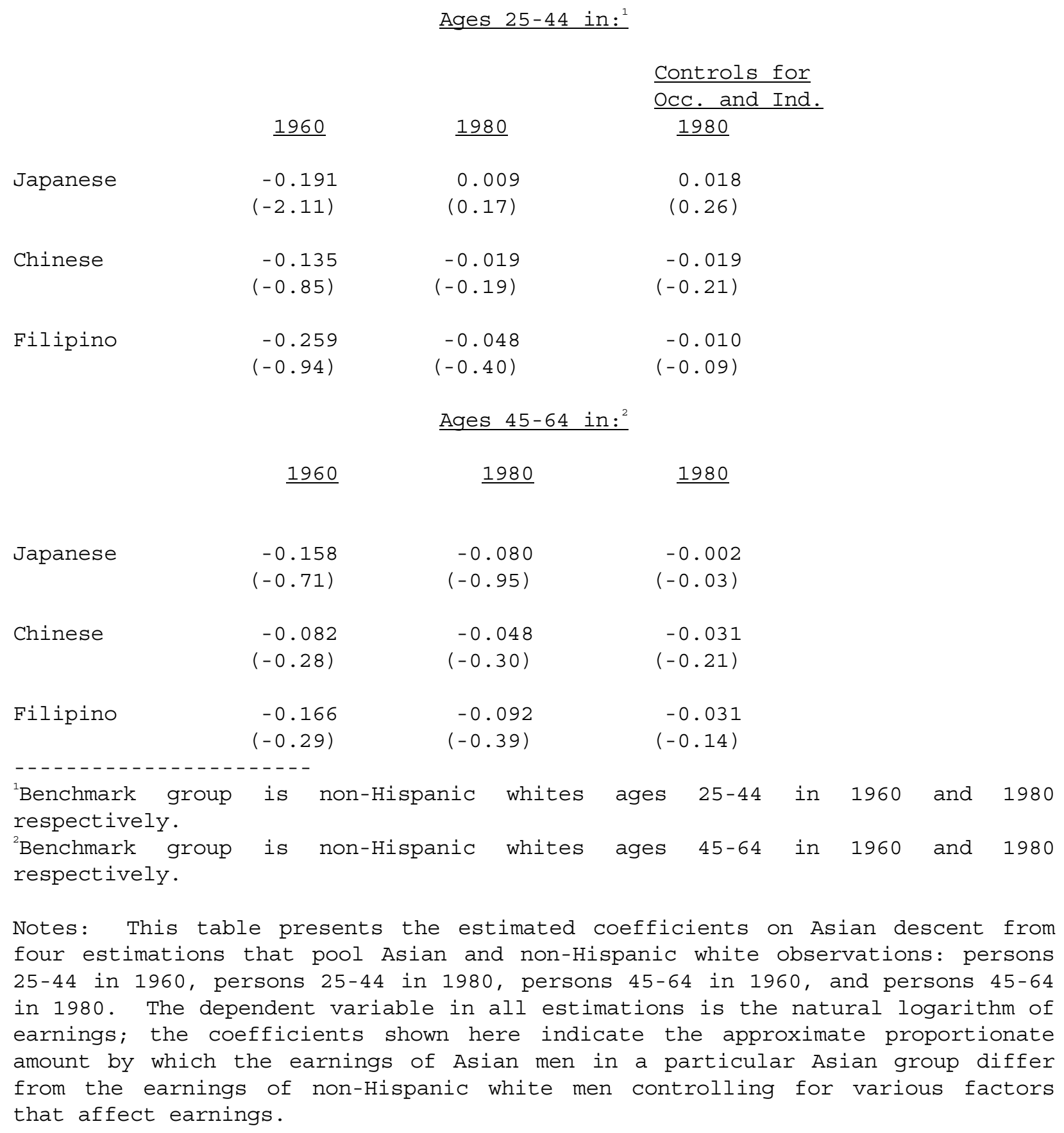


Table 5: Percentage Distribution and Percentage Change in Distribution of Occupations, U.S.-born Men 25-64 Years Old, 1960 and 1980

\begin{tabular}{|c|c|c|c|c|c|c|}
\hline & \multicolumn{5}{|c|}{$\begin{array}{l}\% \Delta \text { for whites } \\
1960 \text { to } 1980\end{array}$} & \multirow[t]{2}{*}{$\begin{array}{l}\frac{\circ}{\circ} \Delta \text { for Asians } 1960 \text { to } \\
1980\end{array}$} \\
\hline & 1960 & 1980 & & 1960 & 1980 & \\
\hline & & \multicolumn{2}{|c|}{ Non-Hispanic Whites } & \multicolumn{2}{|r|}{ Japanese } & \\
\hline Professional & 10.0 & 14.5 & $45.0 \%$ & 14.0 & 21.7 & $55.0 \%$ \\
\hline Technical & 1.5 & 2.8 & $86.7 \%$ & 2.6 & 5.2 & $100.0 \%$ \\
\hline Sales & 7.2 & 8.9 & $23.6 \%$ & 6.5 & 9.1 & $40.0 \%$ \\
\hline Clerical & 7.0 & 6.5 & $-7.1 \%$ & 9.2 & 8.8 & $-4 \cdot 3 \frac{\circ}{0}$ \\
\hline Craft & 23.7 & 23.0 & $-3.0 \%$ & 22.5 & 20.4 & $-9.3 \%$ \\
\hline Operators & 20.6 & 18.1 & $-12.1 \%$ & 10.1 & 7.4 & $-26.7 \%$ \\
\hline Farm Labor & 5.9 & 2.9 & $-50.8 \%$ & 12.2 & 7.3 & $-40.2 \%$ \\
\hline Service Labor & 4.7 & 6.7 & $42.6 \%$ & 3.5 & 5.6 & $60.0 \%$ \\
\hline Personal Household Labor & 0.1 & 0.0 & $-100.0 \%$ & 0.4 & 0.1 & $-75.0 \%$ \\
\hline Laborer & 6.1 & 5.2 & $-14.8 \%$ & 7.1 & 3.6 & $-49.3 \%$ \\
\hline \multirow[t]{2}{*}{ Other } & 13.3 & 11.4 & $-14 \cdot 3 \%$ & 11.9 & 10.8 & $-9.2 \%$ \\
\hline & & \multicolumn{2}{|c|}{ Chinese } & \multicolumn{2}{|r|}{ Filipino } & \\
\hline Professional & 22.4 & 32.2 & $43.8 \%$ & 6.3 & 9.8 & $55.6 \%$ \\
\hline Technical & 2.4 & 6.4 & $166.7 \%$ & 3.1 & 3.9 & $25.8 \%$ \\
\hline Sales & 9.1 & 9.5 & $4.4 \%$ & 0 & 5.7 & NA \\
\hline Clerical & 12.9 & 11.2 & $-13.2 \%$ & 10.9 & 9.1 & $-16.5 \%$ \\
\hline Craft & 13.4 & 12.4 & $-7.5 \%$ & 25 & 23.8 & $-4.8 \%$ \\
\hline Operators & 11.5 & 5.7 & $-50.4 \%$ & 18.8 & 16.9 & $-10.1 \%$ \\
\hline Farm Labor & 0.5 & 0.8 & $60.0 \%$ & 1.6 & 3.1 & $93.8 \%$ \\
\hline Service Labor & 7.2 & 7.6 & $5.6 \%$ & 12.5 & 12.2 & $-2.4 \%$ \\
\hline Personal Household Labor & 0 & 0 & NA & 0 & 0 & NA \\
\hline Laborer & 3.3 & 1.9 & $-42.4 \%$ & 20.3 & 8.7 & $-57.1 \%$ \\
\hline Other & 17.3 & 12.3 & $-28.9 \%$ & 1.5 & 6.8 & $353.3 \%$ \\
\hline $\begin{array}{l}\text { Source: Estimates based } \\
\text { and the } 1980 \text { Census of }\end{array}$ & $n t$ & 1960 & $\begin{array}{l}\text { sus of } \\
\text { rcent }\end{array}$ & ion, & $\begin{array}{l}\text { percent } \\
\text { Sample. }\end{array}$ & Public Use Sample \\
\hline
\end{tabular}


Table 6: Percentage Distribution by Region of Residence and Urban Location, U.S.-born Men 25-64 Years Old, 1960 and 1980

\begin{tabular}{|c|c|c|c|c|c|c|c|}
\hline & Calif. & Hawaii & $\begin{array}{l}\text { North- } \\
\text { east }\end{array}$ & $\begin{array}{c}\text { North } \\
\text { Central }\end{array}$ & South & $\begin{array}{c}\text { Other } \\
\text { West }\end{array}$ & Urban \\
\hline \multicolumn{8}{|l|}{1960} \\
\hline Japanese & 38.9 & 48.4 & 0.6 & 4.1 & 0.8 & 7.2 & 81.8 \\
\hline Chinese & 35.9 & 34.9 & 13.4 & 4.3 & 4.8 & 6.7 & 93.3 \\
\hline Filipino & 28.1 & 56.2 & 3.2 & 4.7 & 3.1 & 4.7 & 78.1 \\
\hline White & 8.5 & 0.0 & 25.8 & 32.3 & 26.4 & 7.0 & 61.4 \\
\hline \multicolumn{8}{|l|}{1980} \\
\hline Japanese & 38.6 & 46.0 & 1.6 & 3.7 & 1.8 & 8.3 & 88.1 \\
\hline Chinese & 43.9 & 23.0 & 13.6 & 5.4 & 6.9 & 7.2 & 96.7 \\
\hline Filipino & 36.4 & 41.2 & 4.3 & 4.4 & 5.3 & 8.4 & 83.2 \\
\hline White & 11.4 & 0.3 & 19.5 & 26.8 & 31.3 & 10.7 & 80.6 \\
\hline
\end{tabular}

Source: Estimates based on the 1960 Census of Population, 1 percent Public Use Sample and the 1980 Census of Population, 5 percent A Public Use Sample. 
Table 7: Schooling Expenditures for Prototypical U.S.-born Asian Man in 1960 and 1980 Labor Force Relative to U.S. Average

Year of Education

$\begin{array}{lll} & 1960 & 1980 \\ \text { Japanese } & 1.19 & 1.16 \\ \text { Chinese } & 1.18 & 1.12 \\ \text { Filipino } & 1.14 & 1.07\end{array}$

Notes: Entries represent the summation of expenditures per pupil in primary and secondary public education relative to the U.S. average, over the years in which the mean age respondent of each Asian group attended primary and secondary school, weighted by the distribution of Asian men in each group who were in California, Hawaii, or the rest of the United States. It was assumed that residents of a state were educated in that state and those not in California or Hawaii were in states with the U.S. average of expenditures per pupil. We ignore that within a state Asian children may systematically go to schools of a different quality than white children. 
Table 8: Labor Force Participation Rates, U.S.-born Men, 1960 and 1980

$\begin{array}{lcccc}1960 & \text { Japanese } & \text { Chinese } & \text { Filipino } & \text { White } \\ \begin{array}{l}\text { Percent in } \\ \text { Labor Force }\end{array} & 96.6 & 95.2 & 90.5 & 94.7 \\ \begin{array}{l}\text { Relative to } \\ \text { Whites }\end{array} & 1.02 & 1.01 & .96 & 1.00 \\ \begin{array}{l}\text { 1980 } \\ \begin{array}{l}\text { Percent in } \\ \text { Labor Force }\end{array}\end{array} & 92.8 & 91.5 & 92.9 & 90.2 \\ \begin{array}{l}\text { Relative to } \\ \text { Whites }\end{array} & 1.03 & 1.01 & 1.03 & 1.00\end{array}$

Notes: The labor force participation rate is the percent of men in the labor force at the time of the census. 
Table 9: Asian/White Earnings Ratios, Adjusting for Agricultural Employment and Self-Employment, Evaluated at Asian-Specific Values of Skills and Characteristics, U.S.-born Men, Ages 25-64, 1960

$$
\text { (t-statistics in parentheses) }
$$

$$
\text { Japanese Chinese Filipino }
$$

$\begin{array}{lccc}\text { Annual Earnings } & & \\ \\ \begin{array}{l}\text { Controlling for Employment } \\ \text { in Agriculture }\end{array} & \begin{array}{c}0.84 \\ (-1.47)\end{array} & \begin{array}{c}0.87 \\ (-1.49)\end{array} & \begin{array}{c}0.65^{* *} \\ \text { Controlling for }\end{array} \\ \begin{array}{l}0.79^{* *} \\ \text { Self-Employment }\end{array} & 0.88 & 0.61^{* *} \\ & (-2.02) & (-1.34) & (-3.05)\end{array}$

Hourly Earnings

$\begin{array}{lccc}\text { Controlling for Employment } & 0.78^{* *} & 0.85^{*} & 0.72^{* *} \\ \text { in Agriculture } & (-2.32) & (-1.88) & (-2.20) \\ \text { Controlling for } & 0.81^{*} & 0.87 & 0.72^{* *} \\ \text { Self-Employment } & (-1.84) & (-1.56) & (-2.13)\end{array}$

\footnotetext{
Difference in predicted log earnings is statistically significant at .05 level.

Difference in predicted log earnings is statistically significant at .10 level.

Notes: The adjusted ratios shown here are computed from the anti-logs of predicted earnings evaluated at 1960 Asian-specific mean levels of all explanatory variables. T-statistics for the difference in predicted log earnings are shown in parentheses.
} 
Table 10: Percent by Schooling Level who Reported on the 1980 Census Speaking Only English or Speaking English Very Well, U.S.-born Men, 25-64 Years Old

$$
\text { Japanese Chinese Filipino white }
$$

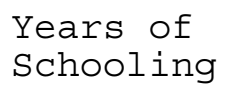

$\begin{array}{cllll}0-8 & 62.45 & 43.75 & 73.83 & 85.73 \\ 9-11 & 76.52 & 74.42 & 91.28 & 95.32 \\ 12 & 87.77 & 87.14 & 96.34 & 97.52 \\ 13-15 & 93.00 & 90.08 & 94.83 & 97.87 \\ 16+ & 96.41 & 94.68 & 92.82 & 98.76\end{array}$


Table 11: Earnings of Asian Men by Years of Schooling Relative to Non-Hispanic Whites, U.S.-born Men, Ages 25-64, 1960

(t-statistics in parentheses)

Japanese Chinese Filipino

Annual Earnings

$\begin{array}{rccr}8 \text { years of school } & 0.85 & 1.14 & 0.76^{*} \\ & (-1.32) & (1.32) & (-1.73) \\ 12 \text { years of school } & 0.77^{* *} & 0.81^{* \star} & 0.63^{* *} \\ & (-2.21) & (-2.17) & (-2.86) \\ 16 \text { years of school } & 0.70^{* *} & 0.76^{* \star} & 0.56^{* *} \\ & (-2.94) & (-2.81) & (-3.64)\end{array}$

Hourly Earnings

\begin{tabular}{|c|c|c|c|}
\hline 8 years of school & $\begin{array}{c}0.74^{* *} \\
(-2.62)\end{array}$ & $\begin{array}{c}0.90 \\
(-1.08)\end{array}$ & $\begin{array}{c}0.84 \\
(-1.10)\end{array}$ \\
\hline years of $\mathrm{sc}$ & $\begin{array}{c}0.78^{* *} \\
(-2.16)\end{array}$ & $\begin{array}{c}0.81^{* *} \\
(-2.29)\end{array}$ & $\begin{array}{l}0.76^{*} \\
(-1.79)\end{array}$ \\
\hline rs of & $\begin{array}{c}0.78^{* *} \\
(-2.15)\end{array}$ & $\begin{array}{c}0.85^{*} \\
(-1.73)\end{array}$ & $\begin{array}{l}0.79 \\
(-1.52)\end{array}$ \\
\hline
\end{tabular}

\# Difference in predicted log earnings is statistically significant at .05 level.

Difference in predicted log earnings is statistically significant at .10 level.

Notes: The results show Asian predicted earnings as a percent of non-Hispanic white predicted earnings (evaluated at Asian-specific values of the explanatory variables). The predicted earnings are based on group-specific regressions evaluated at various years of schooling, 20 years of experience, and Asian group-specific mean levels of all other explanatory variables. T-statistics for the difference in predicted log earnings are shown in parentheses. 
Table 12: Asian/White Earnings Ratios, Excluding and Including English Language Proficiency, Evaluated at Asian-Specific Values of Skills and Characteristics, American-Born Men 45-64 Years Old, 1980

(t-statistics in parentheses)

$$
\text { Japanese Chinese Filipino }
$$

Annual Earnings

$\begin{array}{lllr}\text { Not Controlling for } & 1.04 & 0.96 & 0.94 \\ \text { English Language Proficiency } & (0.86) & (-0.82) & (-0.79) \\ \text { Controlling for } & 1.05 & 0.97 & 0.94 \\ \text { English Language Proficiency } & (1.10) & (-0.62) & (-0.71)\end{array}$

Hourly Earnings

$\begin{array}{lccc}\text { Not Controlling for } & 0.95 & 0.98 & 0.94 \\ \text { English Language Proficiency } & (-0.89) & (-0.45) & (-0.74) \\ \text { Controlling for } & 0.96 & 0.98 & 0.95 \\ \text { English Language Proficiency } & (-0.69) & (-0.27) & (-0.67)\end{array}$

Notes: The adjusted ratios shown here are computed from the anti-logs of predicted earnings evaluated at Asian-specific mean levels of all explanatory variables for the population 45-64 years old in 1980. T-statistics for the difference in predicted log earnings are shown in parentheses. 
Table 13: Asian/White Earnings Ratios, Uncorrected and Corrected for the Omission of English Language Proficiency, Evaluated at Asian-Specific Values of Skills and Characteristics, American-Born Men 25-64 Years Old, 1960

$$
\text { Japanese Chinese Filipino }
$$

Annual Earnings

Not Correcting for

English Language Proficiency

0.77

0.87

0.61

Correcting for

English Language Proficiency

0.78

0.88

0.62

Hourly Earnings

Not Correcting for

English Language Proficiency

0.78

0.85

0.72

Correcting for

English Language Proficiency

$\begin{array}{lll}0.78 & 0.85 & 0.73\end{array}$

Notes: The ratios shown in the first row are simply the adjusted ratios computed from the basic earnings estimation and shown in Table 2. 
Table 14: Percentage Effects of Region of Residence on Hourly Earnings, American-Born Men 25-64 Years Old, 1960 (t-statistics in parentheses)

$\begin{array}{lr}\text { North Central } & \text { Japanese } \\ & .253 \\ \text { South } & (1.01) \\ .031 \\ \text { West } & (0.10) \\ & .050 \\ \text { California } & (0.20) \\ \text { Hawaii } & .177 \\ & (0.75) \\ .218 \\ \end{array}$

$$
\begin{array}{r}
\text { Chinese } \\
-.412 \\
(1.83) \\
-.346 \\
(1.57) \\
.015 \\
(0.08) \\
-.017 \\
(0.12) \\
-.046 \\
(0.34)
\end{array}
$$
Filipino
$-.188$
$(0.51)$
$-.464$
$(1.18)$
$-.175$
$(0.49)$
$-.131$
$(0.43)$
$-.154$
(0.55)

White

$-.027$

(2.66)

$-.146$

(13.52)

$-.012$

(0.77)

(1.50)

.251

(1.08)

Notes: The results shown are coefficients on the geographic variables from regression estimates that include all previously discussed controls, other than occupation and industry, as independent variables. The dependent variable in each regression is the natural logarithm of hourly earnings. The coefficients indicate the approximate proportionate amount by which the hourly earnings of each group in a particular region differ from the hourly earnings of that group in the East, the region which serves as the reference variable in each estimation. 
Expenditures per Pupil on Primary and Secondary Education: California and Hawaii Versus the U.S. Average

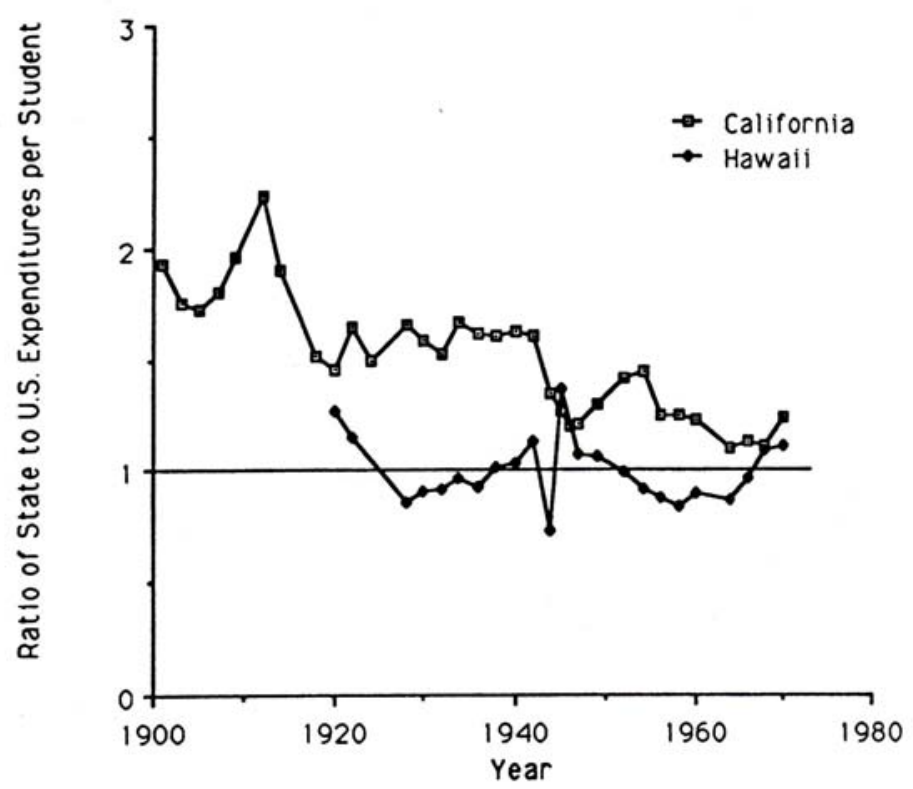

Source: Data are from the Department of Health Education and Welfare, Fall Statistic of Public Schools and the Federal Security Agency, Office of Education, Biannual Survey of Education, reported in the 1900 to 1971 annual Statistical Abstract of the United States.

Notes: Data reported are the ratio of total current expenditures divided by total pupils enrolled in primary and secondary education per state. Figures exclude summer school and adult education. 


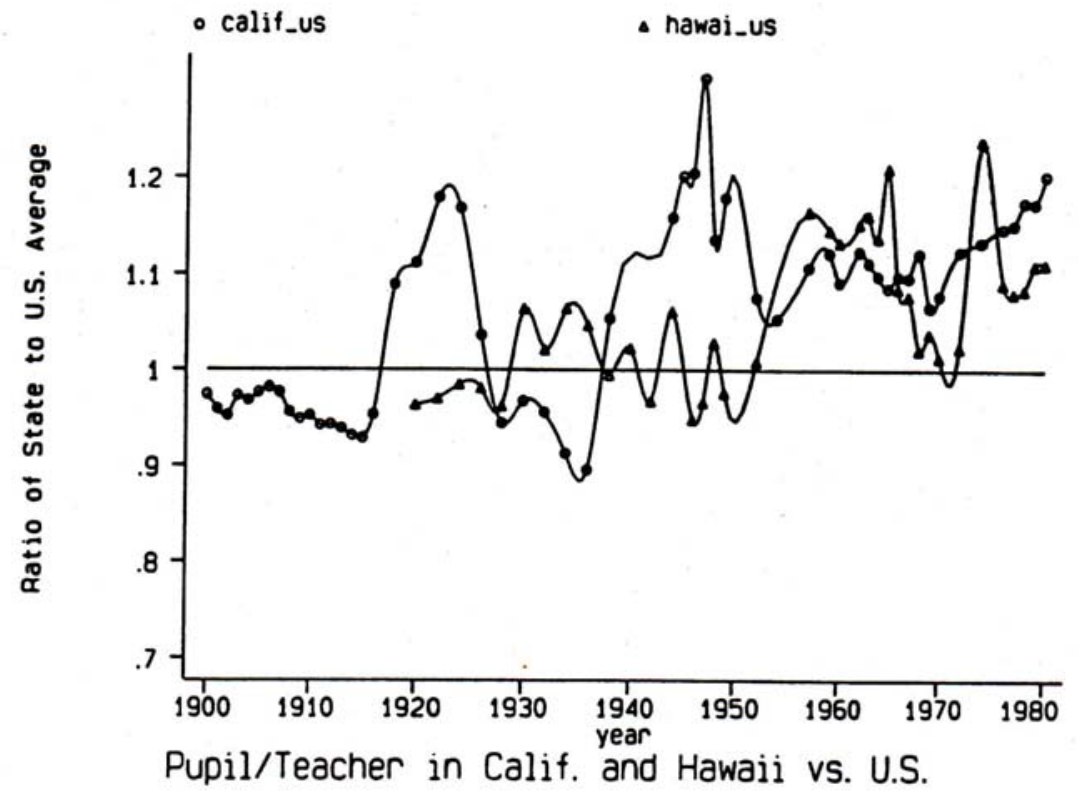

